\title{
Mitigating the socio-economic consequences of mine closure
}

\author{
by M. Ackerman, G. van der Waldt, and D. Botha
}

\section{Synopsis}

An analysis of trends in the mining industry in South Africa reveals a general lack of understanding among mining companies of the significant socio-economic consequences that mine closure may have on affected communities. The existing statutory and regulatory framework of the mining industry makes provision for planned mine closures, but not for unexpected ones. This article presents the findings of an empirical study undertaken to assess the socio-economic consequences and vulnerabilities of communities with the view to proposing a more contingency-based and socio-economic risk mitigation approach for unexpected mine closures. Two cases were analysed, that of the Grootvlei mine in Springs and the Orkney mine. Mainstream contingency planning models, approaches, and principles were synergized and contrasted with the consequences experienced at the two sites. Based on a gap analysis, the respective phases of, and activities associated with, a mine-closure contingency planning approach are suggested for design and implementation by mining companies.

Keywords

contingency planning, disaster, livelihoods, mine closure, mining community, mine closure plan, mitigation, socio-economic vulnerability.

\section{Orientation}

According to Statistics SA's Quarterly Labour Force Survey (Quarter 1: 2016) the total number of mine employees, including employees of subcontractors and employees through labour brokers, declined from 538000 in 2012 to 490000 in 2015. The Chamber of Mines' Facts and Figures (June 2017) indicate that this number decreased to its current (June 2017) number of 457698 employees. Approximately 4.5 million dependents are supported by the sector. A significant number of families, therefore, depend on this industry for their income and livelihood. It thus stands to reason that mine closure could have a devastating impact on the national economy and on the socio-economic wellbeing of communities in affected areas (Oliveira, 2016; Digby, 2016).

A historical overview of the mining industry in South Africa generally reflects key role-players' lack of understanding of the significant impact that the closure of mines has on industry, society, and the environment. The detrimental effect of closures in the mining industry necessitates a comprehensive and a holistic approach to examine the various dimensions of mine closure and ways to mitigate its socio-economic consequences. The primary purpose of this article is to reflect on an empirical survey undertaken at selected sites to assess the socio-economic consequences of mine closure on communities. The secondary purpose is to present a proposed contingency approach to mine closure planning that would help mitigate the socio-economic consequences of such a closure, especially an unexpected, premature one.

\section{The mining industry's approach to mine closure}

Mine closure can be regarded as part of a mine's life-cycle, which typically culminates in the relinquishment of the mining license, social closure, decommissioning, and rehabilitation (Stacey et al., 2010). The International Council on Mining and Metals (ICMM) uses an integrated approach to closure, which takes the environmental and social matters into account (ICMM 2010). According to Laurence (2006), van Eeden, Lieffering, and du Rand (2009), Olalde (2016), and Oliveira (2016), mine closures have become a contested and controversial matter, with several unresolved issues that usually ultimately are left to government to resolve.

Most mines in South Africa have been in operation for at least 50 years. Fourie and Brent (2008) point out that these mines have benefited from decades of profiteering and relative unchecked activities. Such activities unfortunately also lead to the neglect of the environment and run counter to developmental needs of the communities surrounding the mines (Cronjé and Chenga, 2007; Camargo,

\footnotetext{
* North-West University, South Africa.

(c) The Southern African Institute of Mining and Metallurgy, 2018. ISSN 2225-6253. Paper received Mar. 2017; revised paper received Nov. 2017.
} 


\section{Mitigating the socio-economic consequences of mine closure}

2014). Statutory and regulatory measures (e.g., national legislation) to mitigate the often irresponsible way in which mining was conducted only came into effect after most mines became operational. Therefore, when these older mines were established, the management naturally did not have to consider proactive contingency planning ahead of their possible closure (Swart, 2003; Fourie and Brent, 2008).

The Minerals Act 50 No. of 1991 made provision for measures that a mining company should take when the mine closes at the end of its life-cycle. These measures focused mainly on the restoration of the environment (Fourie and Brent, 2008). However, the socio-economic responsibility of the mining companies toward their host communities was not captured in legislation until the implementation of the Mineral and Petroleum Resources Development Act No. 28 of 2002 (MPRDA). The MPRDA and the Broad-based SocioEconomic Empowerment Charter of South Africa (referred to as the 'Mining Charter') placed pressure on mines to act responsibly and work towards upholding principles of sustainable development within their areas of operation (Cronjé and Chenga, 2007).

The Amendment of the Mining Charter ('Mining Charter 2 '), issued in September 2010, emphasizes the promotion of sustainability, growth, and transformation of the mining industry (Amendment of the Mining Charter of 2010). Mining Charter 3 came into force on 15 June 2017. However, the MPRDA and the respective versions of the Mining Charter are severely limited in their description of the various aspects affecting the socio-economic environment of mining communities. For example, there is reference to 'ghost towns' being the 'unintended consequence of mining operations'. However, details on how a mining community may be affected by the degeneration of their town into a 'ghost town' are not provided. Furthermore, the legislation refers to 'planning for enough resources to meet mine closure requirements' (Mining Charter, Clause 2.8), but again there is no elaboration on what exactly is required from the mining industry regarding actual mine closure.

The challenge for the South African mining industry is to deal with the plethora of problems that typically arise due to mine closures, and particularly premature ones. The difficulties associated with such closures in South Africa revolve mainly around two issues: the rehabilitation or restoration of the environment, and the dependency of the surrounding community on mining activities for employment, services, and a market for local businesses (Fourie and Brent, 2008; Stacey et al., 2010). Planning for a mine closure should thus focus not only on rehabilitating the environment, but also on the various socio-economic aspects of closure. Appropriate action would include a budget that provides for the added financial burden to mining companies when planning proactively for a possible mine closure.

There is a growing ethical consciousness (sense of corporate social responsibility) in the mining industry that unused mines may no longer be abandoned. An abandoned mine refers to an area formerly used for mining or mineral processing where closure is incomplete and for which the title holder still exists. Mine owners are expected by law to leave behind decommissioned infrastructure and put in place sustainable economic arrangements that do not hamper opportunities for communities to function once a mine is closed (Stacey et al., 2010). The current state of mine closure in South Africa is generally characterized by reluctance on the part of the mining companies, and even government, to take responsibility for issues surrounding the closure and the costs involved in rehabilitating the mining site (van Eeden et al., 2009; Olalde, 2016; Oliveira, 2016).

\section{General socio-economic consequences of mine closure}

Studies by van Eeden, Lieffering, and du Rand, (2009), Stacey et al., (2010), and du Plessis (2011) identified the general socio-economic consequences of mine closure for communities. These consequences are expounded below.

\section{Confusion about managing social risks}

In most cases, communities were not prepared beforehand for the loss of employment and ensuing poverty. Most affected mining communities suffered from shock. Both the emotional and economic spheres of the inhabitants' existence were affected. This process also impacts social structures and the economic wellbeing of a mining community. Studies indicated a strong relationship between unemployment, emotional issues, and health problems such as hypertension, insomnia, and psychological maladies like depression and feelings of uncertainty. Participants also reported feelings of helplessness and anger.

\section{Inappropriate training for self-employment}

The mining communities also experienced social changes related to job loss, for example unemployment and poverty. Even though plans for skills development and job creation schemes were proposed in the MPRDA, in the past these interventions were not realized in time to ameliorate the consequences of closure for the mineworkers. These individuals had acquired skills only for employment in the mining industry, and job creation schemes failed as well (du Plessis, 2011).

\section{Illegal occupation of empty mine houses and ensuing vandalism}

Mineworkers lose their right to housing when the mine closes. However, their dwellings are left abandoned and are then inhabited by illegal occupants. This clearly impacts negatively on the existing social structures and on the safety of the neighbourhoods. Mining sites are stripped of usable metal, which is then sold to metal recyclers. The infrastructure and facilities of the closed mine are often vandalized. Mining operations cannot re-open unless the infrastructure is rehabilitated, which would be at an extremely high cost to the new mine owner (du Plessis 2011).

\section{Damage caused by pollution and ecological degradation}

The pollution and ecological degradation caused by continual mining is a major concern. Minewater pollution is already a serious issue in South Africa. Abandoned mine shafts and illegal mining in these shafts also constitute a serious problem for mining communities. If mine dumps are not treated, particles containing hazardous chemicals are blown from the dumps. Mining houses have developed mine closure 


\section{Mitigating the socio-economic consequences of mine closure}

toolkits and best practices to address the issues of sustainable development and to improve the practices associated with mine closure. This is done in order to retain the social license that allows them to carry on mining adjacent to these communities in the future.

There is a growing awareness in the mining industry that it is imperative to plan ahead for mine closure (Laurence, 2006 , p. 285). This is particularly applicable to unexpected closures. Globally, codes of best practices as well as toolkits have been developed that help mining houses comply with the legal requirements of the MPRDA and the Mining Charter, as well as the goals of sustainable development (Gammon, 2002 in Stacey et al., 2010). The best practices and mine closure toolkits seek to address the following concerns of stakeholders when a mine's operations cease:

> The mine owners/operators wish to achieve liabilityfree closure within a reasonable timeframe

> The government does not want to be left with large financial or social liabilities

> Communities want the opportunity at least to maintain, but preferably improve, their quality of life

> The socio-economic activities around the mine need to continue in the absence of mining activities

> The environment must be rehabilitated to a point where pollution does not pose an unmanageable threat to life or its processes, and a dynamic equilibrium can be reached over time (Stacey et al., 2010).

\section{Planning for mine closure}

Mine closures should be designed, planned, and managed so that they adhere to the principles that uphold sustainable development. Fourie and Brent (2008) suggest that the principles of project management should be applied to address the challenges of planning for mine closure. Project management is the body of knowledge concerned with principles, techniques, and tools used in planning, controlling, monitoring, and reviewing projects (Business Dictionary, 2013). Fourie and Brent (2008) developed a mine closure model (MCM) that is based on the Project Management Body of Knowledge (PMBOK) to provide a structured approach for a desired outcome. The advantages of using the MCM in planning mine closures is that it promotes proactive planning. The MCM also promotes transparency and encourages the allocation of funding for the closure expenses at the beginning of the process (Fourie and Brent, 2008). The proactive nature of this model offers valuable perspectives regarding a more contingency-based approach to mine closure.

A further instrument for the planning of mine closures is the Socio-Economic Assessment Toolbox (SEAT), which was developed by Anglo American in 2003. SEAT equips personnel by improving their understanding, planning, implementing of, and accounting for mine closure (Anglo American, 2009). From the point of view of socio-economic consequences, the toolbox adds significant value by guiding the design of a comprehensive profile of the operations and the host mining community. This includes the following actions:

> Identification of key stakeholders within the community for effective engagement

> Profiling the community's key socio-economic development needs
- Assessing the impact of operations

> Addressing the socio-economic impact during mine operation and in case of closure.

\section{Contingency planning: a conceptual and contextual orientation}

The fundamental aim of general planning is improving the use of time, human capital, and resources in order to achieve an organization's objectives (Knipe et al., 2002). Van Niekerk (2006) emphasizes that planning efforts as contingency instruments in the context of disasters should have as their main aim the preservation of life, livelihoods, and property. Mitome and Speer (2001) and Choularton (2007) explain that contingency plans should enable proactive actions to safeguard the livelihoods of affected communities. To this Godschalk et al., (1999) add that such planning should be based on lessons learnt from similar, previous events.

In the context of a mine closure, a contingency plan should foster a proactive approach to mitigate the socioeconomic consequences of such an event. Contingency planning is defined by the United Nations International Strategy for Disaster Reduction (ISDR, 1999, p. 18) as '... a management process that analyses specific potential events or emerging situations that might threaten society or the environment and establishes arrangements in advance to enable timely, effective and appropriate responses to such events and situations.' Choularton (2007, p. 3) adds that contingency planning can be regarded as '... a process, in anticipation of potential crisis, of developing strategies, arrangements and procedures to address the humanitarian needs of those adversely affected by crises'. Contingency planning can also be viewed as a 'management tool used to analyse the effects of a potential crisis and ensure that adequate preparedness measures are in place' (ISDR, 1999, p. 12).

It should, however, be stressed that no matter how carefully a management team formulates, implements, and evaluates its strategies, unforeseen events can make a planned strategy relatively obsolete in a short space of time. Contingency planning is especially useful to analyse the impact of potential crises. These impact assessments ensure that adequate and appropriate arrangements are made in advance to respond in a timely, effective, and appropriate way to the needs of the affected population(s).

Managing the processes of contingency planning remains a major challenge for mine management beset with changing circumstances such as competing demands and limited staff, time, and resources (Choularton, 2007). A few basic components are part of typical contingency models and documents and could be considered vital to any contingency plan. The first component addresses the issue: Who will be in charge? The answer may include a detailed exposition of the roles and responsibilities of contingency plan managers and logistics managers (Wisner et al., 2012).

There are different approaches to contingency planning and its processes. The most prominent and widely-used approaches entail scenario building (Choularton, 2007), project management (Visitask, 2011), and strategic planning (Scott-Martinet, 2006). In addition to these approaches, various models were designed to guide contingency planning 


\section{Mitigating the socio-economic consequences of mine closure}

in a disaster context. Some of the most prominent of these include the linear model employed by Disaster Risk International (DRI), the cluster model of the Inter-Agency Standing Committee (IASC), and the process model used by the International Red Cross and Red Crescent Movement (IRCRC). An analysis of these models provides general insight into the approaches, mechanisms, and components needed to address contingencies resulting from a hazardous event.

According to van der Waldt (2011), a contingency plan should answer the questions: what, where, and how much action will take place? An important function of contingency planning is strengthening individuals' capacity to meet the needs that develop due to disasters. In this way, they will be able to respond to the identified post-disaster needs (Kadzatsa, 2011). A contingency plan should also cover communication between managers and the role-players who are involved actively when responding to an emergency. This component of a contingency plan is referred to as the communication system. An integral part of such a communication system comprises a central reporting area, central communications centre, or contact person who has direct access to the contingency plan manager and other partners, and is in contact with the mining community throughout (Lowrey et al., 2007). A further component of a contingency plan is that there should be access to adequate funding in order to address a situation (Toal, 2013). A literature survey further reveals the following core aspects of a typical contingency plan:

> Scenario development to pinpoint possible events

- Response strategy based on the scenario, including specific intervention objectives, targets, and responsibilities

- Operational plan to implement the response strategy

> Operational support plan that sets out the administrative, logistical, and other supporting requirements of a response, including partnerships

> Preparedness plan proposing actions to improve readiness and responses to specific and general crises

> Budget developed to fund both the preparedness plan and the actual response activities.

These key elements should be used as a guide by mining companies to plan proactively for mine closure in general, and to address potential socio-economic consequences in particular.

\section{Research methodology}

The authors opted for the qualitative research design to obtain 'thick' (data-rich) descriptions of the phenomenon under investigation (Weatington, Cunningham, and Pittenger, 2010, p. 526). The methodology consists of two research procedures, a literature review and an empirical study. A robust literature review was conducted to map out the main issues in the field of study. A synthesis was made of the theories, approaches, principles, and models associated with the following themes: disaster risk reduction, contingency planning, vulnerability, sustainable development, corporate social responsibility, and livelihood (i.e. CARE's Household Livelihood Security Model). This synthesis served as general conceptual and analytical framework for a thematic assessment of the socio-economic consequences of mine closure.

The framework provided the foundation from which the basic livelihood of families could be assessed as well as their mechanisms for coping in the absence of such livelihoods. The authors were given access to documents from Helping Hand (Solidarity), which was involved directly with socioeconomic issues at the time of the mine closure. Life stories were also collected in person and compiled from media documents such as newspaper articles, which describe the mineworkers' and their dependents' personal experiences of the mine closures. Official documents issued by Government and articles published by the mining industry, in magazines, and journal articles were also collected and interpreted.

Furthermore, the research was done within the parameters of an ethical code of conduct (Weatington, Cunningham, and Pittenger, 2010), as prescribed by the Ethical Committee of the research entity under whose auspices the study was undertaken. Participation was voluntary and interviews took place in the environment of the participant's choice. Confidentiality was a priority and participants involved in the semi-structured interviews, focus groups, and compilation of life stories were assured that their contributions would remain anonymous.

The empirical investigation consisted of case-study analyses, a focus-group interview, semi-structured interviews, and observation.

\section{Case study analyses}

The closure of two mines formerly owned by liquidated Pamodzi Gold Ltd., namely the Orkney and Grootvlei mines, was investigated. These two cases were deliberately chosen based on the fact that the mines were closed without prior warning or planning, mainly due to the liquidation of the mining company concerned.

During April 2009, Aurora Empowerment Systems negotiated to take over the ownership of the mines, after the previous owners, Pamodzi Gold Ltd., were liquidated. The takeover process was finalized in October 2009. The liquidation of Pamodzi was unexpected, since this was an established, prospering black economic empowerment (BEE) company, which had been active in one of the richest goldproducing areas in the world, Orkney, since 2008. The Pamodzi-owned mines included the Springs Grootvlei, and Orkney mines as well as the President Steyn mine in Welkom. It was expected that by 2010, Pamodzi would increase its output of gold to 1 million ounces per annum. Instead, from early 2009, Pamodzi struggled to remunerate all of its workers (van der Walt, 2009). The following realities occurred at the two mines under investigation. Insufficient remuneration: Mineworkers did not receive their full salaries and only certain shafts were in operation. Workers struggled to make ends meet, and when the mines closed in April 2009, they were sent home without remuneration (van der Walt, 2009).

Emergency aid: During the period April to October 2009, the mineworkers required emergency food aid. Helping Hand, a welfare organization affiliated to and partially funded by the labour union Solidarity, began providing food parcels to the unemployed mineworkers (Esterhuizen, 2015). Schools in Orkney and Springs also launched projects to feed the 


\section{Mitigating the socio-economic consequences of mine closure}

affected children. Parents began collecting funds to support the mineworkers and their children (van der Walt, 2009). New (mis)management: In October 2009, the Orkney and Grootvlei mines were placed under the management of Aurora Management Systems Ltd., which undertook to purchase the liquidated mines from Pamodzi Gold Ltd. (Williams, 2009). The President Steyn mine was bought by the Harmony Gold group in December 2009 (Competition Tribunal, 2009, p. 1). Most mineworkers were under the impression that their situation was restored. Six shafts at the Aurora Orkney mine and seven shafts at Grootvlei re-opened, raising the hope that the socio-economic conditions in the communities surrounding these mines would change (Williams, 2009). The new owners began to pay out partial salaries from December 2009, but the crisis under the previous owners, as described above, was repeated in 2010 (van Rensburg 2012). From April 2010, most mining activities ceased except for limited care and maintenance activities (Tempelhoff, 2010, p. 12). The workers involved in care and maintenance activities were not remunerated, in spite of working their normal shifts and beyond to keep the mines safe and to prevent the mine and the surrounding environment from being flooded with toxic minewater (Oberholzer, 2010).

According to Joubert (2011), all the shafts at Grootvlei finally closed down early in 2011. This was mainly due to the following factors:

> Safety risks, since mining equipment was not maintained

> The continued non-payment of workers

> Cutting of the electricity supply to the mines due to Aurora's failure to pay Eskom accounts (du Plessis, 2011).

In October 2009, the liquidation of Pamodzi Gold was finalized and the mines were handed over to Aurora (Oberholzer 2010). The closing of the Aurora mines in Orkney and Springs affected an estimated 5300 mineworkers (with dependents) who lost their income (Esterhuizen, 2015). As a result, the mineworkers and their dependents were living in dire circumstances and needed immediate humanitarian assistance. The sudden and unexpected closure of these mines left the surrounding communities in a state of crisis (Klopper, 2011). It also demonstrated the significant impact that the closing of mines has on the socio-economic welfare of communities. These events also highlight the fact that purposeful and proactive contingency planning is essential to mitigate the consequences (Godschalk et al., 1999).

\section{Focus-group interview}

One focus-group interview was conducted at the Orkney mine hostel that served Shaft 4. The Helping Hand organization provided a full list and contact details of employees affected by the closure. A random sample of 15 employees was selected. The purpose of the focus group was to determine the effect this closure had on people's livelihoods and general family life. From the participants' contributions, recommendations were formulated and possible gaps identified to consider when designing a contingency plan.

\section{Semi-structured interviews}

Semi-structured interviews were held with purposive as well as randomly sampled employees and stakeholders to gain a detailed picture of their experiences of the mine closures in question. These interviews included firstly, key persons at the NGO (Helping Hand) who provided regular assistance to the mining communities after the mine closure; secondly, fifteen randomly-sampled mineworkers and their wives in Springs and Orkney. These interviews provided the authors with information on the impact the mine closure had on a personal level. These interviews were conducted approximately four months after the closure of the mines.

\section{Observation}

The two mining communities, Aurora-Orkney and Grootvlei in Springs, were observed by visiting the sites and the surrounding areas, making field notes, and by taking photographs. A few short interviews with business owners and managers were also conducted during the site visits, to establish the impact the mine closures had on them.

\section{Data analysis and findings}

The data was processed through thematic analysis. This involved sorting the data according to themes and phrases which the participants repeated (Oplatka, 2001). The aim of data analysis is to understand the various constitutive elements of the gathered information. This is done by examining the relationship between concepts, constructs, or variables. It also entails artery or channelling and finding patterns or trends that can be identified or isolated, or by determining repeated themes (Mouton, 2006). The Sustainable Livelihood Framework (DFID, 1999) and the CARE Household Livelihood Security Framework (2002) were used to identify themes and categories according to which the collected data could be analysed (Table I). The identified themes or trends were documented and gave the authors a clear and in-depth understanding of the phenomenon.

The analysis was done by examining the three categories mentioned in the livelihood frameworks, namely:

> Assets expressed as different forms of capital (e.g. human, natural, financial, social, and physical) (category A)

> Strategies described as activities of a household in its socio-economic environment (e.g. activities involving production and income, consumption and production, as well as exchange and marketing) (category B)

$>$ Outcomes as results from activities performed in the context of livelihood strategies (e.g. food, nutrition, health, education, water, shelter, personal safety, and community participation) (category C).

In each category, certain themes were identified and listed. The themes were identified according to variables that indicate an increase or decrease in vulnerability of a community or household. These categories and themes, outlining the various dimensions that a comprehensive mineclosure contingency plan should address, are presented in Table I. 


\section{Mitigating the socio-economic consequences of mine closure}

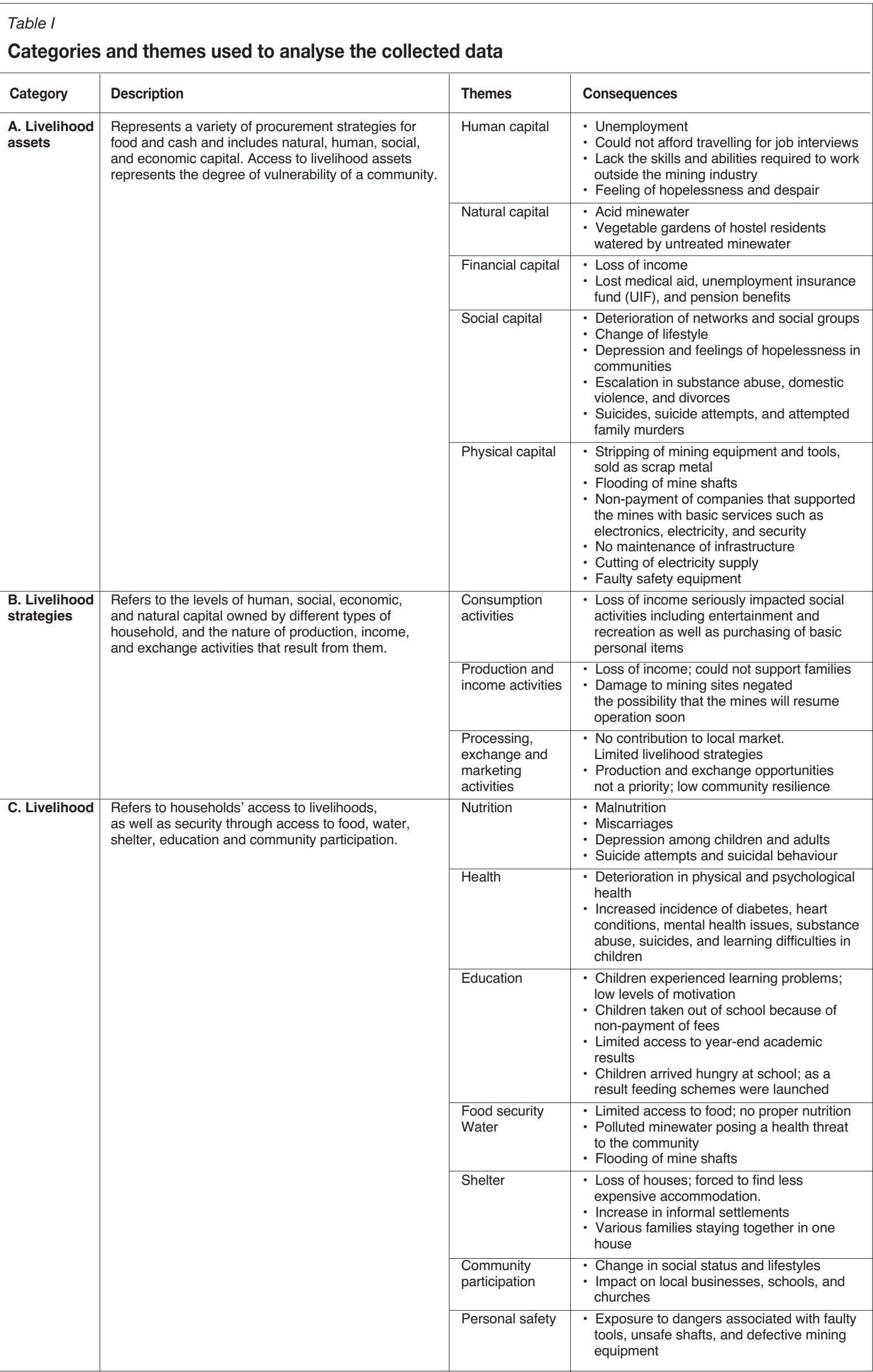

Source: Adapted from the Sustainable Livelihood Framework (DFID, 1999) and the CARE Household Livelihood Security Framework (2002) 


\section{Mitigating the socio-economic consequences of mine closure}

From the data gathered, as outlined in Table I, the following key findings emerged.

High-risk industry: Mineworkers are at risk if they depend solely on the mining industry to help sustain them and their dependents for a full lifespan until and throughout retirement. The mining industry in South Africa, with its large workforce, is currently a high-risk business riddled with problems. Therefore, this industry cannot provide the prospects of a stable working environment, nor promise a secure income to the mineworkers who depend wholly on a salary for their livelihoods. The employees did not prepare in advance for the mine closure; they also did not expect this closure to become permanent.

Additional skills training: The mining industry employs numerous unskilled workers who are then trained and developed for mining operations. However, these workers do not find employment easily in other industries after a mine closure. In most cases, they have to settle for a severely reduced income and a considerably lower quality of life. It is clear that retrenched mineworkers are reluctant to leave their communities at the mine sites. They prefer rather to wait for new owners to take over the mine, which may provide employment.

Official assistance: Mine closures have a devastating effect on the quality of life of the mining community, as well as that of the mineworkers and their families who are affected directly. However, this issue does not receive sufficient attention in the form of official assistance from governmental institutions. In the cases that were investigated, assistance was provided by the mineworkers themselves, by community members providing mutual assistance, as well as by the NGOs together with the labour unions.

Debt counselling: Mineworkers who lost their homes and possessions in most cases still owed money on household items. The need for debt counselling was expressed in the interviews, and such counselling could be one of the measures to protect families from losing their material livelihood in future incidences of mine closures.

Longer term aid: Local churches supported the families who were part of their congregations on a longer term basis than the food aid provided by Helping Hand (HH). However, these church initiatives did not receive any media coverage or outside financial assistance, especially after the media ceased reporting on the situation.
Implementing legislation: There are laws with sufficient provision to prevent the negative effects of a planned, and also an unexpected, mine closure. This entails regulations according to which mine-closure planning and the social and labour plan must be submitted even before exploration of a mining site. However, there is not enough evidence that these acts are implemented and that non-compliance is punished, as prescribed in the Mining Charter (South Africa, 2010). Evidently this was not the case with the mine closures under investigation.

Declaring a disaster situation: The local and provincial governments did not become involved. These institutions could not discern this development as a socio-economic disaster, seeing that the government did not declare the crisis formally as a disaster. This may indicate that disasters caused by natural events receive more attention from government than human-made events.

The concepts that were operationalized, and data collected, clearly indicate that the situations at Grootvlei and Orkney have left the mining communities socio-economically vulnerable. Certain sources have described the events as a 'human tragedy'. There is a need to address these vulnerabilities by means of a detailed contingency plan for mine closure.

\section{Recommendations: a contingency planning approach to mitigate the socio-economic consequences of mine closures}

The thematic analysis (Table I) of the research findings revealed that mine closure plans generally do not comply with the MPRDA, and more significantly, do not make adequate provision for unexpected and unplanned mine closures. A contingency risk-mitigating approach is thus recommended to make adequate provision for the identified socio-economic consequences. A detailed analysis of the complexities associated with socio-economic development in general, as well as the operational details pertaining to a contingency plan such as responsibilities, design, funding, and time frames, falls outside the scope of this article. The purpose is rather to reflect on the findings of the case study survey and to present the contours of a proposed contingency planning approach to mine closure. With this perspective in mind and viewed in terms of socio-economic consequences, it is recommended that mines should incorporate a contingency planning approach in their existing mine closure and social and labour plans. Such an approach should have a twofold function:

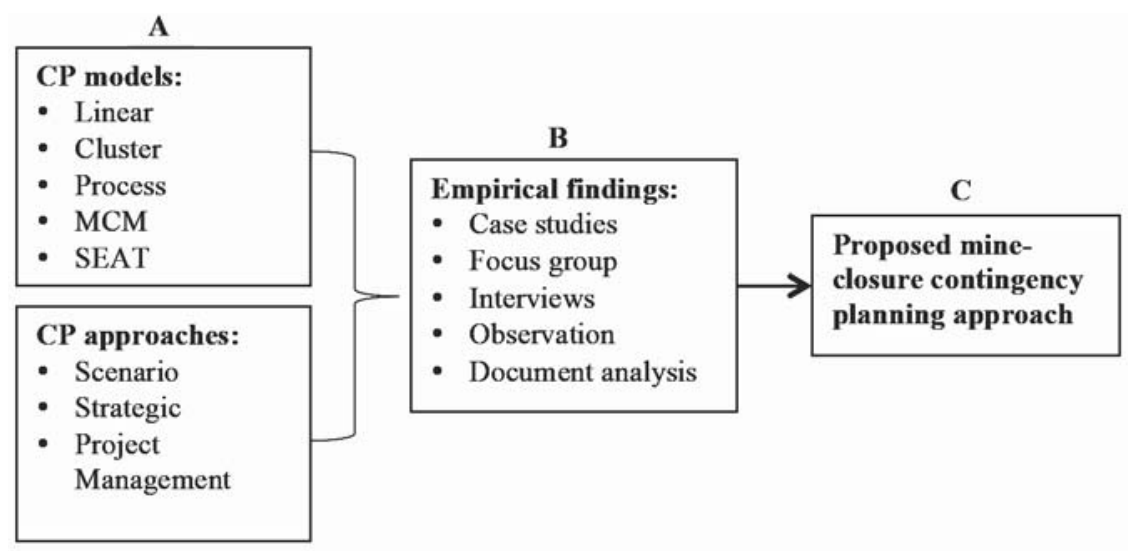

Figure 1-Procedure for the design of a proposed contingency planning approach to mine closure 


\section{Vitigating the socio-economic consequences of mine closure}

> Provide assistance to build resilience into the livelihood assets of mineworkers and their dependents, as well as strategies to ensure favourable outcomes

> Enable a mining company to respond to and meet immediate needs for sustenance in a mining community after an unexpected mine closure.

Based on triangulation of the methodology and data, the procedure depicted in Figure 1 was followed to outline the dimensions and content of a contingency planning approach to mine closure.

The authors analysed the principles, processes, elements, and best practices of the respective contingency planning models, approaches, and 'toolboxes' (A) to establish a synergised perspective. During stage $B$, a verification process was followed to assess the extent to which these elements were evident in the analyses of the two case studies. Based on the gaps identified between processes $\mathrm{A}$ and $\mathrm{B}, \mathrm{a}$ contingency planning approach to mine closure is proposed (C). The fundamental aim of such an approach is to mitigate the effects of a mine closure on the socio-economic vulnerability of mineworkers and their families.

\section{Towards a contingency planning approach: proposed phases}

In order to design and incorporate such a contingency component in mine closure plans, we propose the phases and associated activities as expounded below.

\section{Phase 1: assessment}

During this phase, potential stakeholders and role-players will be identified and a detailed assessment conducted of the socio-economic, political, and physical mining environment. A contingency plan manager should be appointed during this phase to oversee the various activities. The assessment of risks and vulnerability should be supported by a database, which should contain not only detailed information of the mine and its expected life-cycle, but also profiles of the mineworkers in terms of age, skills development, and dependents. The primary function of the database should be to provide the management team with accurate, relevant, and up-to-date information on the various mining operations in the company. As such, the database could also serve as an early warning system. Based on the cluster model, this phase activates the following four clusters:

> Cluster 1: mine profiling

- Cluster 2: mining industry's watchdog

- Cluster 3: scenario planning and early-warning

> Cluster 4: finances and procurement.

\section{Phase 2: planning}

During the second phase, the mining company's management team should prepare a detailed plan covering the dimensions of short-, medium-, and long-term planning as well as the respective strategic, tactical, and operational aspects of such planning. Scenario planning should form part of this phase, and be based on the database developed in the previous phase. The relevant role-players should be invited to participate in this phase. These are the mining community and other stakeholders such as environmental specialists and leaders of the local municipality.

Phase 3: execution

The third phase, execution, documents the actions to address the questions: where and when will the plan be executed?
The inter-agency approach is recommended in this phase, as well as in the previous two (the assessment and planning phases). In the execution phase, the contingency plan manager makes important decisions on utilizing the budget and the logistics that were made available in the strategic planning phase. Activities for this phase should take place after thorough consultation between the parties mentioned in the planning phase. Clear indicators of roles and responsibilities must be planned and communicated beforehand. To avoid duplication and waste of resources, this phase should take place in the clusters responsible for each activity.

In the execution phase the following clusters should be activated:

> Cluster 3: scenario planning and early warning

- Cluster 4: media and communications

> Cluster 5: finances and procurement

> Cluster 6: emergency aid, response, and restore.

\section{Phase 4: review}

The final, review phase should include exercises and workshops for rehearsals and improvement. The mining community should be involved in this phase to advocate the contingency plan in its general application. The focus should be on updating the plan regularly in light of changing circumstances and mining conditions.

Under the leadership of the contingency plan manager, the management team should continuously confirm whether (i) the contingency plan is still relevant to the mining community; (ii) the plan covers the actions needed to address potential socio-economic consequences; and (iii) the plan is feasible by allocating adequate resources. It is recommended that the plan should be updated regularly to ensure that the respective databases profiling the mines of South Africa (e.g. Gemcom, Mine RP Solutions, MRM Mining Services, and Datamine) are up to date. Furthermore, this provides the opportunity to focus on reports from mineworkers who could act as whistle-blowers. These agents attract attention to the warning signs of mine closures and mine owners' noncompliance with the existing social and labour plans. When updating the plan, these reports could be received and analysed to ascertain the appropriate action.

Unexpected mine closure implies more than a 'human tragedy'. It also affects the economy and environment. Furthermore, these calamities occur globally. Therefore, the proposed framework for contingency planning should be expanded and contextualized for other mining industries in developing countries that have a similar socio-economic situation and socio-ideological dynamics. Contingency planning can also be applied and refined in collaboration with mining industries from developed countries worldwide.

\section{Conclusion}

The primary purpose of this article was to outline the socioeconomic consequences of mine closures. The secondary purpose was to make recommendations regarding the mitigation of the consequences. In this regard, a contingency planning approach to mine closure is proposed in order to mitigate potential socio-economic consequences for affected communities. The respective phases and associated core activities were highlighted. The contingency planning approach is based on a gap analysis of empirical research conducted at two mines that underwent unexpected and unplanned closures. 


\section{Mitigating the socio-economic consequences of mine closure}

It is evident that current legislation and regulations for the mining industry in South Africa make adequate provision for planned mine closures, even before mining operations commence. However, cases where mine closure takes place outside the normal project life-cycle are a major concern. Such events lead to severe socio-economic upheaval in the affected communities. A further area that deserves attention in this regard is building the resilience of mining communities and developing additional skills for mineworkers. Mass unemployment may lead to socioeconomic disasters. The further refinement of the proposed contingency planning approach could add significant value in this regard with a view of rendering proactive humanitarian assistance - not only within the South African mining industry, but in cases where unexpected mine closures devastate communities and economies globally.

\section{References}

Anglo AmericAn PLc. 2009. Mine closure.

http://www.angloamerican.com/aal/development/mine-closureplanning/approach [accessed 11 July 2017].

Aurora EMpowerment Systems. 2010.

http://www.auroraempowerment.com/news-pamodzi.html [accessed 16 March 2017].

Business Dictionary. 2013. Project management. http://www.businessdictionary.com/definition/project-management.htm [accessed 2 October 2017].

CAmARgo, R. 2014. Holistic mine closure planning: Social, biophysical and financial. http://www.mineclosuresolutions.com/wpcontent/uploads/2014/05/KEYNOTE-6-Camargo-Ricardo-Holistic-mineclosure-planning-approach-social-biophysical-and-financial.pdf [accessed 2 October 2017].

CARE. 2002. Household livelihood security assessments: a toolkit for practitioners. Tango International. Atlanta, GA. https://scarp.ubc.ca/sites/scarp.ubc.ca/files/Household-LivelihoodAssessment.pdf [accessed 2 October 2017].

Chamber of Mines of South Africa. 2017. Facts and figures. http://www.chamberofmines.org.za/industry-news/publications/factsand-figures [accessed 6 October 2017].

Choularton, R. 2007. Contingency planning and humanitarian action. A review of practice. HPN at ODI, no 59, March. pp. 1-45. http://www.odihpn.org/hpn-resources/hpn-network- papers/contingencyplanning-and-humanitarian-action-a-review-of-practice [accessed 4 October 2017].

Competition TRibunal. 2009. Harmony Gold Mining Company Ltd v Pamodzi Gold Free State (Pty) Ltd. Case nr: 71/LM/Oct09.

CronjÉ, J.F. and Chenga, C.S. 2007. Sustainable social development in the South African mining sector. Development Southern Africa, vol. 26, no. 3. pp. 413-427.

Department For International Development (DFID). 1999. Sustainable livelihoods.

http://www.efls.ca/webresources/DFID_Sustainable_livelihoods_guidance_ sheet.pdf [accessed 1 October 2017].

Digby, C. 2016. Global challenges in mine closure (online video) http://www.miningweekly.com/article/mining-industry-resistant-to-mineclosure-and-rehabilitation-2016-05-27/rep_id:3650 [accessed 5 October 2017].

Du PLESSIS. G. 2011. Solidarity [personal interview]. 5 August. Pretoria.

Esterhuizen, T. 2015. Helping Hand. [personal interview]. 26 March. Pretoria.

Fourie, A. and BRENT, A.C. 2008. A project based model (MCM) for sustainable asset life cycle management. Journal of Cleaner Production, vol. 14, no. 12-13. pp. 1085-1095.

Godschalk, D.R., Beatley, T., Berkey, P., Brower, D.J., and Kaiser, E.J. 1999. Natural Hazard Mitigation: Recasting Disaster Policy and Planning. Island Press, Washington, DC.

ICMM (International Council on Mining and Metals). 2010. Projects. http:// www. Icmm/our-work/projects/mine closure [accessed 22 August 2017]

ISDR (United Nations International Strategy for Disaster Reduction). 1999. International decade for natural disaster reduction. http://www.fire.unifreiburg.de/programmes/ un/idndr/idndr2.html [accessed 1 June 2017].

JOUBERT, J. 2011. Voorlegging in Parlement: pligsversuim lei tot Aurora-lyding. Rapport, 2, 17 April.

KadzatSA, M. 2011. Critical infrastructure. http://acds.co.za/index.php?page=usaid-project [accessed 30 June 2017].
KLOPPER. M. 2011. Helping Hand. [personal interview]. 8 August. Pretoria. KNIPE, A., van der WAldt, G., van Niekerk, D, Burger, D., and Nell, K. 2002. Project Management for Success. Heinemann, Cape Town.

LAURENCE, D. 2006. Optimisation of the mine closure process. Journal of Cleaner Production, vol. 14. pp. 285-298. doi:10.1016/j.jclepro.2004.04.011

Lowrey, W., Evans, W., Gower, K.K., Robinson, J.A., GinTER, P.M., McCormick, L.C., and ABDolrasulnia, M. 2007. Effective media communication of disasters: Pressing problems and recommendations. BMC Public Health, vol. 7. p. 97. doi: 10.1186/1471-2458-7-97

Mitome, Y. and SpeER, K.D. 2001. Embracing disaster with contingency planning. Risk Management, vol. 48, no. 5. pp. 18-20.

Mouton, J. 2006. How to Succeed in your Master's and Doctoral Studies: A South African Guide and Resource Book. Van Schaik, Pretoria.

OBERHolzer, C. 2010. Hedendaagse helde by Aurora. Solidariteit Tydskrif 6.8 November.

OLALDE, M. 2016. SA's failed system of mine closure. https://www.iol.co.za/news/opinion/sas-failed-system-of-mine-closure7117963 [accessed 2 October 2017].

OLIVEIRA, D. 2016. Mine closure, rehabilitation getting more attention from regulators. http://www.miningweekly.com/article/mining-industryresistant-to-mine-closure-and-rehabilitation-2016-05-27 [accessed 5 October 2017].

OPLATKA, I. 2001. Building a typology of self-renewal: reflection upon-life story research. The Qualitative Report, vol. 6, no. 4. pp. 1-18. http://www.nova.edu/ssss/QR/QR6-4/oplatka.html [accessed 13 June 2017].

SCOTT-MARTINET, K. 2006. Strategic contingency planning. https://www.scribd.com/ document/94278384/Scott-Martinet-AbstractStrategic-Contingency-Planning-Ma [accessed 4 November 2017].

South AfricA. 1991. Minerals Act 50 of 1991. Government Printers, Pretoria.

South AFRICA. 2002. Mineral and Petroleum Resources Development (MPRDA) Act 28 of 2002. Government Printers, Pretoria.

South AfRICA. 2010. Amendment of the Broad-based Socio-economic Empowerment Charter for the South African Mining and Minerals Industry. Government Printers, Pretoria.

South Africa. 2017. The Reviewed Broad-Based Black Economic Empowerment Charter for the South African Mining and Minerals Industry ("Mining Charter 3"). Government Printers, Pretoria.

South AFRICA. 2016. South Africa's population. http://www.southafrica.info/about/ people/population.htm [accessed 15 August 2017]

Stacey, J., Naudé. A., Hermanus, M., and Frankel, P. 2010. The economic aspects of mine closure and sustainable development. Literature overview of lessons for the socio-economic aspects of closure. Project 73835, Coaltech Research Association. Report 1 of 2. Centre for Sustainability in Mining and Industry (CSMI), University of the Witwatersrand. pp. 1-32.

Statistics South Africa (StatsSA). 2016. Quarterly Labour Force Survey. Quarter 1: 2016 http://www.statssa.gov.za/publications/P0211/P02111stQuarter2016.pdf [accessed 6 October 2017].

SwART, E. 2003. The South African legislative framework for mine closure. Journal of the South African Institute of Mining and Metallurgy, vol. 103, no. 8. pp. 489-492.

Tempelhoff, E. 2010. Pensioengeld van 2000 by bankrot myn in gedrang. Beeld, 12, 19 March.

ToAL, R. 2013. Fundraising essentials: grant fundraising strategy checklist. http://www.fundsforngos.org/fundraising-guides/fundraising-essentialsgrant-fundraising-strategy-checklist/ [accessed 7 November 2016].

VAN DER WALDT, G. 2011. Adaptive project management: A tool for more realistic municipal planning? Administratio Publica, vol. 19, no. 2. pp. $2-20$.

VAN DER WALT, N. 2009. Myners huis toe, geen geld. Planne vir noodfondse, skoolhulp aan die gang. Noordwes Beeld, 1. 3 April.

VAN EEDEn, E.S., LIEFFERING, M. and Du RAND, J.F. 2009. Legal issues concerning mine closure and social responsibility on the West Rand. Journal for Transdisciplinary Research in Southern Africa, vol. 5, no. 1. pp. 51-71.

VAN NiEKERK, D. 2006. Disaster risk management in South Africa: The function and the activity towards an integrated approach. Politeia, vol. 25 , no. 2. pp. 95-115.

VAn RensbuRg, D. 2012. Aurora se Pamodzi-plan kry vlerke of duik. Beeld, 7 , 31 March.

VISITASK. 2011. What is project management? http://www.visitask.com/projectmanagement.asp [accessed 4 November 2016].

Weathington, B.L., Cunningham, C.J.L., and PitTenger, D.J. 2010. Research Methods for the Behavioral and Social Sciences. Wiley, New York.

Williams, F. 2009. Pamodzi Gold finaal in hof gelikwideer. Sake 24, 7.7 October.

Wisner, B., Gaillard, J.C., and Kelman, I. (eds). 2012. The Routledge Handbook of Hazards and Disaster Risk Reduction. Routledge, Oxon, MD. 